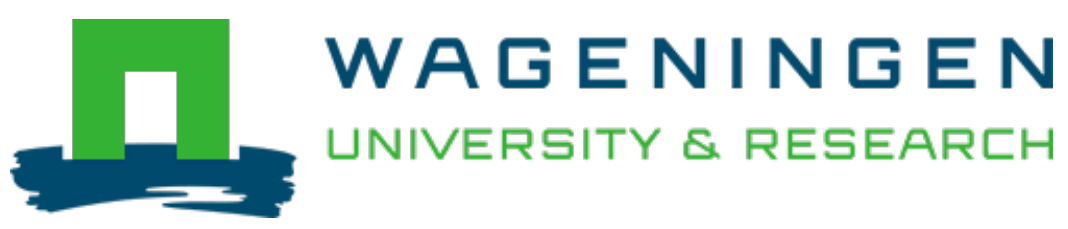

\title{
Biological control in Latin America and the Caribbean: information sources, organizations, types and approaches in biological control
}

Biological control in Latin America and the Caribbean: its rich history and bright future.

Lenteren, J.C.; Bueno, V.H.P.; Luna, M.G.

https://doi.org/10.1079/9781789242430.0001

This article is made publicly available in the institutional repository of Wageningen University and Research, under the terms of article $25 \mathrm{fa}$ of the Dutch Copyright Act, also known as the Amendment Taverne. This has been done with explicit consent by the author.

Article 25 fa states that the author of a short scientific work funded either wholly or partially by Dutch public funds is entitled to make that work publicly available for no consideration following a reasonable period of time after the work was first published, provided that clear reference is made to the source of the first publication of the work.

This publication is distributed under The Association of Universities in the Netherlands (VSNU) 'Article $25 \mathrm{fa}$ implementation' project. In this project research outputs of researchers employed by Dutch Universities that comply with the legal requirements of Article $25 \mathrm{fa}$ of the Dutch Copyright Act are distributed online and free of cost or other barriers in institutional repositories. Research outputs are distributed six months after their first online publication in the original published version and with proper attribution to the source of the original publication.

You are permitted to download and use the publication for personal purposes. All rights remain with the author(s) and / or copyright owner(s) of this work. Any use of the publication or parts of it other than authorised under article $25 \mathrm{fa}$ of the Dutch Copyright act is prohibited. Wageningen University \& Research and the author(s) of this publication shall not be held responsible or liable for any damages resulting from your (re)use of this publication.

For questions regarding the public availability of this article please contact openscience.library@,wur.nl 


\title{
Biological Control in Latin America and the Caribbean: Information Sources, Organizations, Types and Approaches in Biological Control
}

\author{
Joop C. van Lenteren ${ }^{1 *}$, Vanda H.P. Bueno ${ }^{2}$, \\ M. Gabriela Luna ${ }^{3}$ and Yelitza C. Colmenarez ${ }^{4}$ \\ ${ }^{1}$ Laboratory of Entomology, Wageningen University, The Netherlands; \\ 'Laboratory of Biological Control, Department of Entomology, \\ Federal University of Lavras, Minas Gerais, Brazil; ${ }^{3}$ CEPAVE, \\ CONICET-UNLP (Centro de Estudios Parasitológicos y de Vectores), \\ La Plata, Argentina; ${ }^{4}$ CABI-UNESP-FEPAF, Botucatu, São Paulo, \\ Brazil
}

\begin{abstract}
Biological control with arthropod natural enemies and microbial control agents has been applied since the year 1895 in Latin America and the Caribbean and is currently used on a very large scale. Sources about the history and current situation of biocontrol in this region were not easy to trace and are, therefore, presented in this chapter. Next, organizations working on biocontrol in this region are listed. This is followed by a description of natural, conservation, classical and augmentative biocontrol with some regional examples. Then, an approach to find, evaluate and use biocontrol agents is sketched, as guidance for research projects. Often, tens to a hundred biocontrol candidates are found in association with a pest. A well organized research approach using evaluation criteria allows for quick exclusion of unsuitable or problematic candidate species. Biocontrol research has limited funding and early elimination of poor candidates results in spending more money on promising candidates. Regulations concerning import and release of agents that have been implemented during the past 30 years are summarized. Effects of these regulations are that prospecting for exotic natural enemies is now very difficult and that fewer new biocontrol agents have become available. Finally, the structure of the book is explained.
\end{abstract}

\subsection{Introduction}

Biological control (biocontrol) is, simply said, the use of an organism to reduce the population density of another organism. It is the most successful, most cost effective and environmentally safest system for pest, disease and weed management (Bale et al., 2008). It is nature's own way to keep numbers of pest organisms at low levels. Biocontrol is present in all ecosystems, both natural and man-made. The result of natural biocontrol is that the earth is green and that plants can produce sufficient biomass to sustain other forms of life. Without biocontrol, the production of energy by plants would be a tiny fraction of what is generated currently.

\footnotetext{
*E-mail: joop.vanlenteren@wur.nl
} 
Developments in biocontrol have been summarized for several world regions and in various handbooks. However, few publications provide historical detail about the development and the current situation of biocontrol in Latin America and the Caribbean. Nonetheless, biocontrol with arthropod natural enemies and microbial control agents has been applied since 1895 on large areas in Latin America and the need was felt for a well documented overview. The main aims of this book are threefold: first to summarize the history; next to describe the current situation; and, finally, to speculate about the future of biocontrol. The history of biocontrol is presented in 30 chapters; most chapters are about individual countries, but some deal with groups of smaller countries and islands. The history was fragmented until now and if information was available it was often in local reports and publications in Spanish or Portuguese that were difficult to obtain. We asked authors of the book chapters to translate and summarize information about developments in biocontrol in their country, and by presenting this knowledge in the current book, we aspire to offer a reasonably complete picture of important historical developments in this region. When authors referred to abstracts, unpublished reports, information leaflets or symposium papers, we asked them to provide pdf versions of this material, so that readers of this book can consult the original material upon which parts of the country-specific chapters were based. These pdf files can be obtained from a website made available by CABI. An ample amount of text, tables and references about this history is provided, because in order to make progress in biocontrol it is essential to know what was done, which projects succeeded, but also which projects failed and the main limitations faced by those projects. Documentation of the pest species, crops, biocontrol agents, locations and type of biocontrol programmes tested will hopefully help to prevent making the same mistakes and stimulate initiation of new projects with biocontrol agents that have been successfully used elsewhere. After summarizing the history, the current situation is described and then the authors present their ideas about the future of biocontrol in their country.

During the data-collection phase for the book, we were astonished by the amount of often unknown practical biocontrol applied in Latin America and the Caribbean. Van Lenteren and Bueno (2003) estimated that the area under augmentative biocontrol in this region was about 4,350,000 ha in the year 2000, but realized that this might be a serious underestimate (Table 1.1). Reliable data for areas and crops protected by classical biocontrol were even more difficult to obtain than those for augmentative biocontrol. In the final chapter of this book, new estimates are given based on data presented in each chapter. The 2018 estimates for areas under augmentative biocontrol alone, amount to more than 31,300,000 ha (see Table 32.1) and are, not surprisingly, much larger than known earlier. Still, these areas are underestimates, as for quite a number of projects up-to-date data were not available. The newly

Table 1.1. Major augmentative biological control programmes in Latin America in the year 2000 (after van Lenteren and Bueno (2003), with additions; areas of $<10,000$ ha not included).

\begin{tabular}{|c|c|c|}
\hline Natural enemy & Pest and crop & Area under control (ha) \\
\hline Trichogramma spp. & $\begin{array}{l}\text { Lepidopteran pests in maize, cotton, sugarcane, } \\
\text { tobacco }\end{array}$ & 1.5 million, Mexico \\
\hline Trichogramma spp. & $\begin{array}{l}\text { Lepidopteran pests in cereals, cotton, sugarcane, } \\
\text { pastures }\end{array}$ & 1.2 million, Latin America \\
\hline AgMNPV virus & Soybean caterpillar in soybean & 1 million, Brazil \\
\hline Entomopathogenic fungi & $\begin{array}{l}\text { Lepidopteran pests in pastures, cassava and } \\
\text { vegetables }\end{array}$ & 0.695 million, Latin America \\
\hline Entomopathogenic fungi & Coffee berry borer in coffee & 0.55 million, Colombia \\
\hline Entomopathogenic fungi & Lepidopteran pests in palm oil plantations & 0.13 million, Colombia \\
\hline Cotesia sp. & Sugarcane borers in sugarcane & 0.4 million, Latin America \\
\hline Egg parasitoids & Soybean stink bugs in soybean & 0.03 million, Latin America \\
\hline Orgilus sp. & Pine shoot moth in pine plantations & 0.05 million, Chile \\
\hline
\end{tabular}


collected data presented in this book indicate that Latin America and the Caribbean may currently have the largest area under biocontrol worldwide.

In this introductory chapter, we first present information on the literature about biocontrol in the region. Then we provide an overview of organizations working on biocontrol in Latin America and the Caribbean. Next, different types of biocontrol are described; an approach to find, evaluate and use biocontrol agents is sketched; and regulations concerning import and release of agents are summarized. Finally, the structure of the book is explained.

\subsection{Literature on Biological Control in Latin America and the Caribbean}

The Inter-American Network of Academies of Sciences (IANAS Regional Report, 2017) recently mentioned that the Latin America region is a biodiversity superpower that includes five of the world's ten most biodiverse countries - Brazil, Colombia, Ecuador, Mexico and Peru - as well as the most biologically diverse area in the world: the Amazon rainforest. South America alone is home to more than $40 \%$ of the earth's biodiversity and over a quarter of its forests, $30 \%$ of its freshwater and nearly $30 \%$ of its arable land, which makes the region a genetic reserve and supplier for the planet.

It is, therefore, not surprising that Latin America has provided many biocontrol agents for other parts of the world, as well as having a rich history in biocontrol in the area itself. However, the history and current situation of biocontrol in Latin America and the Caribbean are, in many cases, difficult to trace and hidden in local reports that are not written in English. Still, for some countries the information has been well summarized in books (e.g. Brazil, Caribbean, Chile, Colombia, Cuba, Mexico and Venezuela) (Table 1.2), though often either in Spanish and Portuguese, which makes this information less accessible to an international readership. Also, several review papers have appeared over the years, partly in English (Table 1.2). Although it is clear that many biocontrol projects have been and are executed in this region, it appeared very difficult to estimate the area under biocontrol based on the material presented in these books and review papers. Most information is qualitative, providing insight into research projects and pests, diseases and weeds for which biocontrol programmes have been developed. From now on, we will often use the word 'pest' as defined by FAO/IPPC (1997), which includes animal pests, weeds and diseases.

\subsection{International and Regional Organizations working on Biological Control in Latin America and the Caribbean}

Several organizations have been active in this region to initiate and coordinate activities on biocontrol. Some of these organizations worked only on biocontrol, while others dealt with biocontrol as part of integrated pest management (IPM) or sustainable agriculture. Table 1.3 gives the names and websites of these organizations, details of which are described in the following sections.

\subsubsection{The Centre for Agriculture and Biosciences International (CABI)}

The oldest organization coordinating research and application of biocontrol in this region, particularly in the Caribbean, is probably CABI. Here follows a short description of the history of the Trinidad station of CABI which we quote from Cock (1985, p. x):

... in November 1928 when J.G. Myers and his wife (I.H. Myers) were sent to the West Indies by the Farnham House Laboratory (subsequently to become the Imperial Parasite Service, the Commonwealth Institute of Biological Control (CIBC), International Institute of Biological Control (IIBC) and now known as CABI). They were 'to study the possibility of biological control for the main pests of agriculture in the British Colonies of tropical America'. Myers visited and worked in all the countries covered in this review except Bermuda and Belize and his work and recommendations, followed by those of the sugar cane entomologist H.E. Box, led to a sharp increase in biological control activity which was only brought to a halt by World War II. In September 1946, F.J. Simmonds of the 
Table 1.2. Books and review papers concerning biological control in Latin America and the Caribbean.

(a) In chronological order

\begin{tabular}{|c|c|}
\hline Year & Regional Latin American and Caribbean reviews and books in chronological order \\
\hline 1973 & $\begin{array}{l}\text { Hagen, K.S., and Franz, J.M. A history of biological control. In: Smith, R.F., Mittler, T. } \\
\text { and Smith, C.N. (eds) History of Entomology. Annual Reviews Inc., Palo Alto, } \\
\text { pp. 433-476 [ENGLISH] }\end{array}$ \\
\hline 1984 & $\begin{array}{l}\text { Bennett, D. and Street, G. The Commonwealth Institute of Biological Control in } \\
\text { integrated pest management programs in Latin America. In: Allen, G. and Rada, A. } \\
\text { (eds) Proceedings of the International Symposium: The Role of Biological Control } \\
\text { in Pest Management. Ottawa University Press, Santiago, Chile, pp. 41-53 } \\
\text { [ENGLISH] }\end{array}$ \\
\hline 1985 & $\begin{array}{l}\text { Cock, M.J.W. (ed.) A review of biological control of pests in the Commonwealth } \\
\text { Caribbean and Bermuda up to 1982. Technical Communication No. 9, Common- } \\
\text { wealth Institute of Biological Control. Commonwealth Agricultural Bureaux, } \\
\text { Farnham Royal, UK [ENGLISH] }\end{array}$ \\
\hline 1989 & $\begin{array}{l}\text { DeLoach, C., Cordo, H.A. and Crouzel, I.S. Control biológico de malezas. Editorial } \\
\text { El Ateneo, Buenos Aires, Argentina [SPANISH] }\end{array}$ \\
\hline 1989 & $\begin{array}{l}\text { Altieri, M.A., Klein-Koch, C., Trujillo, J., Gold, C.S., Campos, L.S. and Quezada, J.R. } \\
\text { El control biologico clasico en America Latina en su context historico. [Classical } \\
\text { biological control in Latin America in its historical context]. Manejo Integrado de } \\
\text { Plagas Costa Rica, No. 12, pp. 87-107 [SPANISH] }\end{array}$ \\
\hline 1996 & $\begin{array}{l}\text { Zapater, M.C. (ed.) El Control Biológico en América Latina. IOBC/NTRS, Buenos } \\
\text { Aires, Argentina [SPANISH] }\end{array}$ \\
\hline 1999 & $\begin{array}{l}\text { Altieri, M.A. and Nichols, C.I. Classical biological control in Latin America. In: } \\
\text { Bellows, T.S. and Fisher, T.W. (eds) Handbook of Biological Control. Academic } \\
\text { Press, San Diego, California, pp. 975-991 [ENGLISH] }\end{array}$ \\
\hline 2003 & $\begin{array}{l}\text { van Lenteren, J.C. and Bueno, V.H.P. Augmentative biological control of arthropods } \\
\text { in Latin America. BioControl 48, 123-139 [ENGLISH] }\end{array}$ \\
\hline 2008 & $\begin{array}{l}\text { Alves, S.B. and Lopes, R.B. (eds) Controle microbiano de pragas na América } \\
\text { Latina. Fapesp/Fealq. São Paulo, Brazil [PORTUGUESE] }\end{array}$ \\
\hline 2008 & $\begin{array}{l}\text { Barreto, R.W. Latin American weed biological control science at the crossroads. In: } \\
\text { Julien, M.H., Sforza, R., Bon, M.C., Evans, H.C., Hatcher, P.E., Hinz., H.L. and } \\
\text { Rector, B.G. (eds) Proceedings of the XII International Symposium on Biological } \\
\text { Control of Weeds. CAB International, Wallingford, UK, pp. 109-121 [ENGLISH] }\end{array}$ \\
\hline 2008 & $\begin{array}{l}\text { Hilje, L. and Saunders, J.I. Manejo integrado de plagas en Mesoamérica: aportes } \\
\text { conceptuales [Integrated pest management in Mesoamerica: conceptual } \\
\text { contributions]. Editorial Tecnológica de Costa Rica, Cartago, Costa Rica } \\
\text { [SPANISH] }\end{array}$ \\
\hline 2009 & $\begin{array}{l}\text { Bettiol, W. and Morandi, M.A.B. Biocontrole de doenças de plantas: uso e perspectivas } \\
\text { [Biological control of plant disease: use and perspectives]. Embrapa Meio Ambiente, } \\
\text { Jaguariúna, São Paulo, Brazil. [PORTUGUESE] }\end{array}$ \\
\hline 2012 & $\begin{array}{l}\text { Fuentes, F., Ferrer, F.R. and Salas, J.L. Reseña Histórica del Control Biológico en } \\
\text { Centroamérica y el Caribe [History of biological control in Central America and } \\
\text { the Caribbean]. Ed. Académica Española, LAP LAMBERT Academic Publishing } \\
\text { GmbH\& Co, Saarbrucken, Germany [SPANISH] }\end{array}$ \\
\hline 2014 & $\begin{array}{l}\text { Bettiol, W., Rivera, M.C., Mondino, P., Montealegre, J.R. and Colmenárez, Y.C. } \\
\text { Control biológico de enfermedades de plantas en América Latina y el Caribe } \\
\text { [Biological control of plant diseases in Latin America and the Caribbean]. Faculdad } \\
\text { de Agronomia, Universidad de la Republica, Montevideo, Uruguay [SPANISH] }\end{array}$ \\
\hline 2018 & $\begin{array}{l}\text { Cotes, A.M. (ed.) Control biológico, de fitopatógenos, insectos y ácaros [Biological } \\
\text { control of phytopathogens, insects and mites]. Vol 1. Applicaciones y perspectivas } \\
\text { [Applications and perspectives]. Vol 2. Agentes de control biológico [Biological } \\
\text { control agents]. AgroSavia Editores, Mosquera, Colombia [SPANISH] }\end{array}$ \\
\hline
\end{tabular}


Table 1.2. Continued.

(b) By country

\begin{tabular}{ll}
\hline Country & Country reviews and books \\
\hline Argentina & Cabrera Walsh G., Briano, J., Enrique de Briano, A., and Anderson, F.E. (2014) \\
& Malezas e invasoras de la Argentina [Invasive weeds in Argentina]. In: Fernández \\
& O.A., Leguizamón E.S. and Acciaresi H.A. (eds) Control Biológico de Malezas \\
& [Biological Control of Weeds]. Tomo I, Ecología y manejo. Editorial de la \\
& Universidad Nacional del Sur. Ediciones. Bahía Blanca, Argentina, pp. 801-821 \\
& [SPANISH] \\
& See country-specific chapters in Zapater (1996) ${ }^{\mathrm{a}}$ [SPANISH] and Bettiol et al. \\
& (2014) $^{\mathrm{b}}$ [SPANISH] \\
Bee sections in Cock (1985) [ENGLISH] & \\
Barbados & See sections in Cock (1985) [ENGLISH] ${ }^{c}$ \\
Belize & Rogg, H.W. (2000a) Manual de Entomología Agrícola de Bolivia [Handbook of \\
Bolivia & Agricultural Entomology of Bolivia]. Abya-Yala, Quito, Ecuador. 926 pp. \\
& Rogg, H.W. (2000b) Manual Manejo Integrado de Plagas en Cultivos Tropicales \\
& [Handbook of Integrated Pest Management in Tropical Crops]. Abya-Yala, Quito, \\
& Ecuador. 117 pp. [SPANISH]
\end{tabular}

Brazil Bueno, V.H.P. (ed.) (2000/2009) Controle Biológico de Pragas: Produção Massal e Controle de Qualidade [Biological pest control: mass production and quality control]. Editora UFLA, Lavras, Brazil. 1st edition, 207 pp.; 2nd edition, 429 pp. [PORTUGUESE]

Parra, J.R.P., Botelho, P.S.M., Corrêa-Ferreira, B.S. and Bento, J.M.S. (eds.) (2002) Controle Biológico no Brasil. Parasitóides e Predadores (Biological Control in Brazil. Parasitoids and Predators). Ed.Manole, São Paulo, 635pp. [PORTUGUESE]

See country-specific chapters in Zapater (1996) [SPANISH] and Bettiol et al. (2014) [SPANISH]

Chile Rojas, S. (2005) Control biológico de plagas en Chile. Historia y avances [Biological control of pests in Chile. History and advances]. Instituto de Investigaciones Agropecuarias. Centro Regional de Investigación La Platina. Edit. Ograma, La Cruz, Chile [SPANISH]

See country-specific chapters in Zapater (1996) [SPANISH] and Bettiol et al. (2014) [SPANISH]

Colombia Palacios, F. (ed.) (1993) Control biológico en Colombia: historia, avances y proyecciones [Biological control in Colombia: history, progress and projections]. Universidad Nacional de Colombia, Palmira, Colombia. 282 pp. [SPANISH]

Carreño, A.M. (2001) Fundamentos de control biológico de plagas [Fundamentals of biological pest control]. Universidad Nacional de Colombia sede Medellín, Colombia [SPANISH]

See country-specific chapters in Zapater (1996) [SPANISH] and Bettiol et al. (2014) [SPANISH]

Costa Rica See country-specific chapters in Zapater (1996) [SPANISH] and Bettiol et al. (2014) [SPANISH]

Cuba Vázquez, L.L. and Pérez, N. (2016) Control biológico [Biological control]. In: Funes, F. and Vázquez, L.L. (eds). Avances de la agroecología en Cuba. Estación experimental de Pastos y Forrajes Indio Hatuey. Matanzas. pp. 169-182 [SPANISH]

See country-specific chapter in Bettiol et al. (2014) [SPANISH]

Dominica

See sections in Cock (1985) [ENGLISH] 
Table 1.2. Continued.

\begin{tabular}{l} 
(b) By country \\
\hline Country \\
\hline $\begin{array}{l}\text { Dominican } \\
\text { Republic }\end{array}$ \\
Ecuador \\
\\
EI Salvador \\
Guatemala \\
French Guiana, \\
Guadeloupe, \\
Martinique
\end{tabular}

Country reviews and books

Pérez-Gelabert, D. (2008) Arthropods of Hispaniola (Dominican Republic and Haiti): a checklist and bibliography. Zootaxa 1831, 1-530 [ENGLISH]

See country-specific chapter in Bettiol et al. (2014) [SPANISH]

Klein-Koch, C. (1989) El control biológico de plagas en Ecuador. [Biological control of pests in Ecuador]. Ministerio de Agricultura y GTZ, Quito, Ecuador. Sanidad Vegetal, 4 (4), 5-20. [SPANISH]

See country-specific chapters in Zapater (1996) [SPANISH] and Bettiol et al. (2014) [SPANISH]

No review papers/books available

See country-specific chapter in Zapater (1996) [SPANISH]

Ryckewaert P. and Rhino B. (2017) Insectes et acariens des cultures maraîchères en milieu tropical humide: reconnaissance, bio-écologie et gestion agroécologique [Insects and mites of vegetable crops in humid tropical environment: recognition, bio-ecology and agro-ecological management]. Ed. Quae, Versailles, France, 152 pp. [FRENCH]

Guyana
Haiti
Honduras
Jamaica
Mexico

Nicaragua
Panama
Paraguay
Peru

See sections in Cock (1985) [ENGLISH]

Pérez-Gelabert, D. (2008) Arthropods of Hispaniola (Dominican Republic and Haiti): a checklist and bibliography. Zootaxa 1831, 1-530. [ENGLISH]

No review papers/books available

See country-specific chapters in Zapater (1996) [SPANISH] and Bettiol et al. (2014) [SPANISH]

See sections in Cock (1985) [ENGLISH]

Arredondo-Bernal, H.C. and Rodríguez-del-Bosque, L.A. (eds) (2008) Casos de Control Biológico en México [Cases of biological control in Mexico]. Ed. Mundi-Prensa, Mexico. 423 pp. [SPANISH]

Arredondo-Bernal, H.C. and Rodríguez-del-Bosque, L.A. (2015) Casos de Control Biológico en México [Cases of biological control in Mexico]. Vol. 2. Biblioteca Básica de Agricultura, Colegio de Postgraduados, México [SPANISH]

See country-specific chapter in Bettiol et al. (2014) [SPANISH]

See country-specific chapter in Zapater (1996) [SPANISH]

See country-specific chapter in Bettiol et al. (2014) [SPANISH]

See country-specific chapter in Bettiol et al. (2014) [SPANISH]

Aguilar, P. (1980) Apuntes sobre el control biológico y el control integrado de las plagas agrícolas en el Perú [Notes on biological control and integrated control of agricultural pests in Peru]. Revista Peruana de Entomología, 23(1), 83-110. [SPANISH]

Beingolea, O. (1990) Sinopsis sobre el control biológico de plagas insectiles en el Perú, 1909-1990 [Synopsis on the biological control of insect pests in Peru, 1909-1990]. Revista Peruana de Entomología, 33, 105-112. [SPANISH]

See country-specific chapters in Zapater (1996) [SPANISH] and Bettiol et al. (2014) [SPANISH]

\section{Puerto Rico \\ Remaining \\ Caribbean \\ islands \\ Suriname
Trinidad and Tobago

Gallardo-Covas, F. (2017) Biological control of insect pests in Puerto Rico. Journal of Agriculture of the University of P.R. 101, 153-163 [ENGLISH]

See sections in Cock (1985) [ENGLISH] and Bettiol et al. (2014) [SPANISH]

van Dinther, J.B.M. (1960) Insect pests of cultivated plants in Suriname. Bulletin Agricultural Experiment Station, Suriname 76, 1-159 [ENGLISH]

See sections in Cock (1985) [ENGLISH] 
Table 1.2. Continued.

\begin{tabular}{ll}
\hline (b) By country & \\
\hline Country & Country reviews and books \\
\hline Uruguay & Bentancourt, C.M. and Scatoni, I.B. (2001) Enemigos naturales: Manual ilustrado \\
& para la agricultura y la forestación [Biological control agents: Illustrated manual \\
& for agriculture and forestry]. Universidad de la República, Facultad de \\
& Agronomía, Montevideo, Uruguay [SPANISH] \\
& See country-specific chapters in Zapater (1996) [SPANISH] and Bettiol et al. (2014) \\
& [SPANISH] \\
Venezuela & Ferrer, F. (2001) Biological control of agricultural insect pests in Venezuela; \\
& advances, achievements, and future perspectives. Biocontrol News and \\
& Information 22.3, 67-74. (ENGLISH) \\
& See country-specific chapter in Bettiol et al. (2014) (SPANISH) \\
\hline
\end{tabular}

aZapater (1996) mainly summarized arthropod biocontrol

'Bettiol et al. (2014) summarized biocontrol of diseases

${ }^{c}$ Cock (1985) summarized arthropod and weed biocontrol

Table 1.3. International organizations and websites.

\begin{tabular}{|c|c|c|}
\hline Acronym & Full name & Website \\
\hline CABI & Centre for Agriculture and Biosciences International & https://www.cabi.org \\
\hline CARDI & $\begin{array}{l}\text { Caribbean Agricultural Research and Development } \\
\text { Institute }\end{array}$ & http://www.cardi.org \\
\hline CATIE & $\begin{array}{l}\text { Centro Agronómico Tropical de Investigación y } \\
\text { Enseñanza (Tropical Agriculture Research and } \\
\text { Higher Education Center) }\end{array}$ & http://catie.ac.cr/en/ \\
\hline CGIAR & $\begin{array}{l}\text { Consortium of International Agricultural Research } \\
\text { Centers }\end{array}$ & www.cgiar.org \\
\hline CIAT, Colombia & International Center for Tropical Agriculture & http://ciat.cgiar.org \\
\hline $\begin{array}{r}\text { CIMMYT, } \\
\text { Mexico }\end{array}$ & $\begin{array}{l}\text { International Maize and Wheat Improvement } \\
\text { Center }\end{array}$ & www.cimmyt.org \\
\hline CIP, Peru & International Potato Center & http://cipotato.org/ \\
\hline FAO & $\begin{array}{l}\text { Food and Agriculture Organization of the United } \\
\text { Nations }\end{array}$ & http://www.fao.org/americas/en/ \\
\hline IICA & $\begin{array}{l}\text { Inter-American Institute for Cooperation on } \\
\text { Agriculture }\end{array}$ & http://www.iica.int/ \\
\hline IOBC Global & International Organization for Biological Control & www.iobc-global.org \\
\hline IOBC/NTRS & $\begin{array}{l}\text { Neotropical Regional Section of the International } \\
\text { Organization for Biological Control }\end{array}$ & http://www.iobcntrs.org/ \\
\hline OIRSA & $\begin{array}{l}\text { International Regional Organization for Plant } \\
\text { Protection and Animal Health }\end{array}$ & https://www.oirsa.org \\
\hline
\end{tabular}

CIBC was stationed at the Imperial College of Tropical Agriculture (which became the St Augustine Campus of the University of the West Indies) to study the natural enemies for control of the weed Cordia curassavica (Jacq.) R. \& S. on the island of Mauritius. This led to the establishment of the West Indian Station CIBC. He was joined by F.D. Bennett in 1952 and in 1958 when Simmonds became director of CIBC, Bennett became entomologist in charge of the
West Indian Station. Ever since Simmonds arrived in Trinidad the CIBC has played a dominant role in biological control in the region. During the intensive programme against sugar cane stem borers the CIBC ran a substation in Barbados. However, as is to be expected, the region is developing its own expertise and in recent years the Caribbean Agricultural Research and Development Institute (CARDI) has become involved in the rearing, shipment 
and release of parasites in the Lesser Antilles from its unit in Barbados which developed from the CIBC substation.

The CABI station in Trinidad and Tobago was for a long time the centre arranging the introduction of most biocontrol agents into the Caribbean region. In 1985, CABI published an extensive summary of biocontrol projects in the Caribbean and Bermuda (Cock, 1985). Contributors to this book have used information from Cock (1985) to summarize the history of biocontrol for a number of Caribbean islands.

CABI is an international not-for-profit organization and has partners in 49 member countries across the world. Currently, CABI has two units in the region: one in Trinidad and Tobago and another in Brazil. The Trinidad and Tobago centre (CABI, 2019a):

... researches and identifies agricultural pests and diseases, and works to mitigate the threats of invasive species. Farmers are supported in their integrated pest management (IPM) choices, and encouraged to implement sustainable crop management and production strategies ... The centre also collaborates with Ministries of Agriculture in the region, and provides information to guide policy.

The Brazil centre (CABI, 2019b) 'operates across the whole of Latin America, providing ... scientific knowledge, information and expertise to the Latin American nations'. It also implements projects related to IPM, biocontrol of invasive weeds, and agricultural and forest pests. Examples of current involvement of CABI in the region are biocontrol of pink hibiscus mealybug in the Caribbean, fall armyworm in Latin America, rubber vine in Brazil and blackberry on the Galapagos islands.

\subsubsection{The Caribbean Agricultural Research and Development Institute (CARDI)}

Next to CABI activities in the region, the Englishspeaking Caribbean islands and mainland areas have collaborated in a regional research system, starting in 1946 and coordinated by the Imperial College of Tropical Agriculture (ICTA), then in 1955 by the Regional Research Centre (RCC) and since 1975 by CARDI. CARDI's objectives
(CARDI, 2019) are 'providing for the research and development needs of the agriculture of the region as identified in national plans and policies, as well as providing an appropriate research and development service to the agricultural sector of member countries'. Member countries of CARDI are Antigua and Barbuda, Barbados, Belize, Dominica, Grenada, Guyana, Jamaica, Montserrat, St Kitts-Nevis, St Lucia, St Vincent and the Grenadines and Trinidad and Tobago. They provide the funding for the Institute's core budget, while funding for projects comes also from donor agencies. Parts of CARDI's projects concern biocontrol and these are mentioned in the country-specific chapters later in the book.

\subsubsection{The Consortium of International Agricultural Research Centers (CGIAR)}

The CGIAR was founded in 1971 and its 15 international centres constitute the core of the organization (www.cgiar.org). CGIAR's vision is to: (i) reduce poverty and hunger; (ii) improve human health and nutrition; and (iii) enhance ecosystem resilience through high-quality international agricultural research, partnership and leadership. Three of its centres are located in Latin America: the International Maize and Wheat Improvement Center (CIMMYT, Mexico, established in 1966), the International Center for Tropical Agriculture (CIAT, Colombia, established in 1967) and the International Potato Center (CIP, Peru, established in 1971). These three centres, as well as sub-units of other CGIAR centres, have activities in the field of biocontrol within the framework of IPM and sustainable agriculture.

\subsubsection{The Inter-American Institute for Cooperation on Agriculture (IICA)}

Since 1942, the Inter-American Institute for Cooperation on Agriculture (IICA), with its headquarters in Costa Rica, has supported the efforts of its Member States (34, all over the American hemisphere) to achieve agricultural development and rural well-being. Some of the projects executed under the umbrella of IICA concern aspects of biocontrol related to sustainable agricultural production. 


\subsubsection{The Tropical Agriculture Research and Higher Education Center (CATIE)}

The Centro Agronómico Tropical de Investigación y Enseñanza (The Tropical Agriculture Research and Higher Education Center, CATIE) was also founded in Costa Rica in 1942. Its mandate is research and education in agriculture and natural resources in the American tropics. Today, CATIE is an international, non-for-profit institution dedicated to research, higher education and outreach in agricultural sciences, natural resources and related topics in the American tropics. CATIE has 14 member countries: Belize, Bolivia, Brazil, Colombia, Costa Rica, the Dominican Republic, El Salvador, Guatemala, Honduras, Mexico, Nicaragua, Panama, Paraguay and Venezuela. CATIE's mission is to 'Increase sustainable and inclusive human well-being in Latin America and the Caribbean, promoting education, research and innovation for development, sustainable management of agriculture and conservation of natural resources'. Projects of CATIE may involve research and teaching in biocontrol.

\subsubsection{The International Regional Organization for Plant Protection and Animal Health (OIRSA)}

Founded in 1953 in El Salvador, the objective of the International Regional Organization for Plant Protection and Animal Health (OIRSA) is to support the efforts of the member states, to achieve development of their animal and plant health plans and to strengthen their quarantine systems. OIRSA's member countries are Belize, Costa Rica, the Dominican Republic, El Salvador, Honduras, Guatemala, Mexico, Nicaragua and Panama. An example of involvement of OIRSA in biocontrol is given in Chapter 4 (Belize) under classical biocontrol of the pink hibiscus mealybug.

\subsubsection{The United Nations Food and Agriculture Organization Regional Office for Latin America and the Caribbean (FAO)}

FAO's Regional Office has been located since 1955 in Chile, with sub-regional offices in Panama and Barbados. It 'works on a series of priority areas in order to move towards the total eradication of hunger in Latin America and the Caribbean' (FAO, 2019). The Latin American and Caribbean Office has been and is still involved in activities related to biocontrol, like the programme on biocontrol of the pink hibiscus mealybug.

\subsubsection{The Neotropical Regional Section of the International Organisation for Biological Control (IOBC/NTRS)}

The Neotropical Regional Section of IOBC (IOBC/NTRS) is a regional branch of the International Organisation for Biological Control (IOBC/Global) and was founded in 1989 in Argentina. It is a not-for-profit organization that aims to promote the development and utilization of biocontrol in Latin America as a way to reduce or avoid losses inflicted by noxious animals and plants. IOBC/NTRS has a working group on parasitoids of the Neotropical Region. In addition, IOBC/NTRS assists in the organization of courses in biocontrol, as well as in networking among the biocontrol researchers in the neotropics.

\subsubsection{National universities and research institutes}

Information on many universities and national research institutes working on biocontrol can be found in the country chapters and will, therefore, not be listed here.

\subsubsection{National biological control, entomological, microbiological and phytopathological societies}

Many countries in the region have entomological societies that organize regular national meetings, which include sections or symposia on biocontrol (Table 1.4). Mexico and Peru have specific societies for biocontrol, and the Brazilian Entomological Society organizes biannual meetings on biocontrol with participation by scientists of other Latin American and Caribbean countries. Biocontrol issues may also be addressed 
Table 1.4. Scientific societies involved in biocontrol in Latin America.

\begin{tabular}{ll}
\hline Name of society & Website \\
\hline Sociedad Entomológica de Argentina & http://www.seargentina.com.ar/ \\
Sociedad Boliviana de Entomologia & https://sociedadbe.webs.com/ \\
Sociedade Brasileira de Entomologia (SBE) & http://www.sbe.ufpr.br/ \\
Sociedade Entomológica do Brasil (SEB) & https://seb.org.br/ \\
Sociedad Chilena de Entomologia & http://www.insectachile.cl/ \\
Sociedad Colombiana de Entomologia & http://www.socolen.org.co/ \\
Sociedad Entomológica Ecuatoriana & http://entomologia.ec/ \\
Sociedad Entomológica del Perú & http://sepperu.com.pe/ \\
Asociación Peruana de Control Biológico (APCB) & https://www.facebook.com/Asociaci \%C3\%B3n- \\
& Peruana-de-Control-Biol\%C3\%B3gico- \\
& APCB-660619824001577/ \\
Sociedad Mexicana de Control Biológico (SMCB) & https://www.smcb-mx.org \\
Sociedad Mexicana de Entomologia & http://www.socmexent.org/ \\
Sociedad Venezolana de Entomologia & https://ojs3.entomotropica.org/ \\
\hline
\end{tabular}

during the regional meetings of phytopathological societies (united in the Asociación Latinoamericana de Fitopatología (ALF)) and microbiological societies (united in Asociación Latinoamericana de Microbiología (ALAM)).

\subsection{Types of Biological Control}

Biological control is one of the most environmentally safe and economically profitable pest management methods (Cock et al., 2010, and references therein). In biocontrol, parasitoids, predators, pathogens, herbivores and antagonists are used to reduce populations of pests, diseases and weeds. Several types of biocontrol can be distinguished (Table 1.5). In this book we will mainly use the terms that are most often applied in the literature: natural, conservation, classical and augmentative biocontrol.

\subsubsection{Natural control}

Natural control $(\mathrm{NC})$ or natural biological control is an ecosystem service (Millennium Ecosystem Assessment, 2005) whereby pest organisms are reduced by naturally occurring beneficial organisms. This type of control occurs in all of the world's ecosystems, whether natural or agroecosystems, and on land as well as in water. In economic value, it is the greatest contribution to agriculture (Waage and Greathead, 1988).
However, due to pesticide applications, the full benefit of NC is often curtailed. Many chapters in this book report on prospecting for native natural enemies and the role they play in NC. An example is NC of the diamondback moth, Plutella xylostella (L.), in Jamaica. Sampling of diamondback moth populations in several locations during a 5-year period resulted in finding 34 species of natural enemies: five parasitoids, $11 \mathrm{insect}$ predators, 15 species of spiders and three species of entomophagous fungi. These natural enemies together caused high pest mortality (see Chapter 20: Jamaica).

\subsubsection{Conservation biological control}

In conservation biological control (ConsBC) farmers try to protect and stimulate the performance of naturally occurring natural enemies (DeBach, 1974). ConsBC currently receives a lot of attention in Latin America and the Caribbean (Wyckhuys et al., 2013). An example is ConsBC of the spiralling whitefly Aleurodicus dispersus Russell in banana in Costa Rica. This pest was mainly a problem in plantations treated with nematicides, which produce vapours that eliminate natural enemies. Natural enemies of the spiralling whitefly were sampled, resulting in the choice of, among others, four species of parasitoids and seven species of predators. Use of a selective nematicide increased natural enemy survival and reduced pest problems (see Chapter 9: Costa Rica). 
Table 1.5. Types of biological control.

\begin{tabular}{|c|c|c|}
\hline Type of biocontrol (reference) & Synonym (reference) & Description \\
\hline $\begin{array}{l}\text { Natural control (NC) (DeBach, } \\
\text { 1964) }\end{array}$ & Natural biological control & $\begin{array}{l}\text { Form of pest control whereby pests are } \\
\text { reduced by naturally occurring beneficial } \\
\text { organisms }\end{array}$ \\
\hline $\begin{array}{l}\text { Conservation biological control } \\
\text { (ConsBC) (DeBach, 1974) }\end{array}$ & & $\begin{array}{l}\text { Human actions that protect and stimulate } \\
\text { the performance of naturally occurring } \\
\text { beneficial organisms }\end{array}$ \\
\hline $\begin{array}{l}\text { Classical biological control } \\
\text { (CBC) (Greathead, 1994) }\end{array}$ & $\begin{array}{l}\text { Inoculative control (van } \\
\text { Lenteren, this chapter); } \\
\text { Importation control } \\
\text { (Nordlund, 1996) }\end{array}$ & $\begin{array}{l}\text { Introduction of relatively low numbers of } \\
\text { beneficial organisms from the area of } \\
\text { origin of the pest with the aim to obtain } \\
\text { permanent control }\end{array}$ \\
\hline $\begin{array}{l}\text { Augmentative biological control } \\
\text { (ABC) (DeBach, 1974) }\end{array}$ & & $\begin{array}{l}\text { Mass production and periodic release of } \\
\text { beneficial organisms without aim to } \\
\text { obtain permanent control }\end{array}$ \\
\hline $\begin{array}{l}\text { Inundative control (van Lenteren, } \\
\text { 1986) }\end{array}$ & & $\begin{array}{l}\text { Periodic release of large numbers of } \\
\text { organisms to obtain immediate control } \\
\text { of the pest in crops with a short } \\
\text { production cycle }\end{array}$ \\
\hline $\begin{array}{l}\text { Seasonal inoculative control (van } \\
\text { Lenteren, 1986) }\end{array}$ & & $\begin{array}{l}\text { Periodic release of relatively low numbers } \\
\text { of organisms to obtain control during } \\
\text { several generations of pests in crops } \\
\text { with a long production cycle }\end{array}$ \\
\hline \multicolumn{3}{|l|}{$\begin{array}{l}\text { Special cases of classical } \\
\text { biological control: }\end{array}$} \\
\hline $\begin{array}{l}\text { Fortuitous control (FBC) } \\
\text { (DeBach, 1974) }\end{array}$ & & $\begin{array}{l}\text { Control of a pest by an accidentally } \\
\text { introduced beneficial organism }\end{array}$ \\
\hline $\begin{array}{l}\text { Neoclassical biological control } \\
\text { (Lockwood, 1993) }\end{array}$ & $\begin{array}{l}\text { New association control } \\
\text { (Hokkanen and } \\
\text { Pimentel, 1989) }\end{array}$ & $\begin{array}{l}\text { Use of exotic beneficial organisms to } \\
\text { control a native pest }\end{array}$ \\
\hline
\end{tabular}

\subsubsection{Classical biological control}

Classical biological control $(\mathrm{CBC})$ is the introduction of relatively low numbers (generally fewer than 1000) of beneficial organisms, usually from a pest's area of origin, to control a pest in an area where it has invaded. Once introduced, the aim is that the biocontrol agent will become established, reproduce, spread and have a self-sustaining effect on the target pest. $\mathrm{CBC}$ has the highest benefit-cost ratios, because financial involvement in research costs is usually not very large, while the profits accumulate each year after release of a successful natural enemy (Cock et al., 2010). CBC is most effective in perennial crops where the pest and natural enemy can coexist indeterminately. Many historical and current $\mathrm{CBC}$ projects, for control of both insect pests and weeds, are mentioned in this book. Latin America and the Caribbean have also provided many species of beneficial insects for $\mathrm{CBC}$ projects in other world regions and these are mentioned in the country-specific chapters. As CBC was the first type of biocontrol to be widely practised, it is often called 'classical' biocontrol (Greathead, 1994). However, the word classical does not explain what method and aim are involved, so several synonyms have been proposed. One synonym is 'importation' biocontrol, because $\mathrm{CBC}$ often refers to importation and release of an exotic natural enemy to control an accidentally introduced pest (Nordlund, 1996; Heimpel and Mills, 2017). We prefer not to use the term importation, because many exotic natural enemies have also been imported for augmentative forms of biocontrol. In our opinion, the term 'inoculative' biocontrol would be more suitable, as the aim is to obtain permanent control of a pest (whether exotic or native) by releasing a relatively limited number of beneficial organisms (whether exotic or native). In this book we will for pragmatic reasons use the term classical 
biocontrol. Two early 20th century examples of CBC in Latin American are the introduction in many countries of the coccinellid predator Rodolia cardinalis (Mulsant) for control of cottony cushion scale (Icerya purchasi Maskell) and the release of the hymenopteran parasitoid Encarsia berlesei Howard for control of the white peach scale (Pseudaulacaspis pentagona (Targioni Tozzetti). Offspring of the biocontrol agents of the thenreleased predators and parasitoids are still around in many countries in this region and keep reducing pest populations. Two recent successes in Latin America and the Caribbean are control of the pink hibiscus mealybug with the parasitoid Anagyrus kamali Moursi and control of the Asian citrus psyllid Diaphorina citri Kuwayama with the parasitoid Tamarixia radiata (Waterston).

\subsubsection{Augmentative biological control}

Augmentative biological control $(\mathrm{ABC})$ is the production and release of native or exotic biocontrol agents to obtain direct pest control, but the agents are not expected to persist from one cropping cycle to the next. Usually two types of $\mathrm{ABC}$ are distinguished: (i) 'inundative' control in short-cycle crops (e.g. vegetables) of up to a few months, whereby biocontrol agents are introduced in very large numbers (hundreds of thousands) per hectare to obtain immediate control; and (ii) 'seasonal inoculative' control in crops with a production cycle of up to many months (e.g. ornamentals), whereby biocontrol agents are introduced in relatively low numbers (thousands to tens of thousands) per hectare to obtain control during several generations of the pest (van Lenteren, 1986). ABC is applied over large areas in various cropping systems in Latin America and the Caribbean. Well known regional examples are the use of species of the egg parasitoid genus Trichogramma for management of Lepidoptera in various crops and the use of Cotesia parasitoids against sugarcane borer (see Chapter 6: Brazil). In addition to the use of parasitoids and predators, Latin America is applying microbial control agents in $\mathrm{ABC}$ projects on a large scale, such as viruses for control of caterpillars in soybean, fungi for control of pests in coffee, cotton and sugarcane, and nematodes for control of soil-borne pests.

\subsubsection{Earliest activities in biological control in Latin America and the Caribbean}

All types of biocontrol that have been described above are used in Latin America and the Caribbean. Some countries were very early in the development and application of biocontrol, whereas others started after the Second World War (Table 1.6). Although classical biocontrol was most often used in most of the countries during the early period, it is remarkable that demonstration of natural control, application of augmentative biocontrol and treatments with entomopathogenic bacteria and fungi were all implemented before 1920 . Table 1.6 presents an overview of the earliest biocontrol activities for each country in the region, and more details about these activities can be found in the countryspecific chapters.

\subsection{Finding, Evaluation and Utilization of Biological Control Agents}

Approaches for finding and evaluation for invertebrate biocontrol agents can be found in Cock et al. (2010) and for microbial biocontrol agents in Ravensberg (2011). Many ideas about biocontrol agent selection have been published, varying from easy approaches such as the collection and release of all natural enemies that might attack the pest (the 'hit-or-miss approach') (DeBach, 1964) to time-consuming research programmes that include behavioural and ecological studies, as well as environmental risk assessments (van Lenteren, 1980; van Driesche and Bellows, 1996; Stiling and Cornelissen, 2005; Heimpel and Mills, 2017; McEvoy, 2018). The hit-or-miss approach was often used in Latin America and the Caribbean, and in particular the many interisland movements of natural enemies by CABI illustrate this tactic. Due to guidelines and regulations applied since the 1990s, this approach is no longer used.

It generally takes about 10 years to find, evaluate, select and eventually release/market a biocontrol agent, which is similar to the time needed to find a new synthetic pesticide. Recently, a list of criteria for evaluation of biocontrol 
Table 1.6. Earliest activities in biological control using arthropod natural enemies or microbial control agents for control of arthropod pests and weeds in each country in Latin America and the Caribbean.

\begin{tabular}{|c|c|c|}
\hline Year & Country & Biological control activity \\
\hline 1884 & Venezuela & Tests using a hymenopteran parasitoid for control of migratory locusts \\
\hline 1895 & Puerto Rico & Documentation of $\mathrm{NC}$ of sugarcane borers by hymenopteran parasitoids \\
\hline 1899 & Argentina & $\begin{array}{l}\text { Export of a phytophagous coleopteran for CBC of snake weed in } \\
\text { the USA }\end{array}$ \\
\hline 1902 & Mexico & $A B C$ of Mexican boll weevil with native predatory mite \\
\hline 1903 & Chile & Import of a coleopteran predator for $\mathrm{CBC}$ of olive black scale \\
\hline 1904 & Peru & $\begin{array}{l}\text { Import of hymenopteran parasitoids and coleopteran predator for CBC } \\
\text { of cotton white scale }\end{array}$ \\
\hline 1911 & Uruguay & Import of an entomopathogenic bacterium for $\mathrm{ABC}$ of locusts \\
\hline 1913 & Colombia & $A B C$ of locusts with an entomopathogenic bacterium \\
\hline 1913 & Suriname & $\begin{array}{l}\text { Documentation of native neuropteran and hemipteran predators of } \\
\text { cocoa thrips }\end{array}$ \\
\hline 1915 & Costa Rica & $A B C$ of locusts with an entomopathogenic bacterium \\
\hline 1915 & $\begin{array}{l}\text { Trinidad and } \\
\text { Tobago }\end{array}$ & $\begin{array}{l}\mathrm{ABC} \text { of froghoppers with hymenopteran parasitoids, neuropteran } \\
\text { predators and entomopathogenic fungi }\end{array}$ \\
\hline 1917 & $\begin{array}{l}\text { Remaining Caribbean } \\
\text { islands }\end{array}$ & Demonstration of $\mathrm{NC}$ of froghoppers by an entomopathogenic fungus \\
\hline 1918 & Jamaica & Import of coleopteran predators for $\mathrm{CBC}$ of banana weevil \\
\hline 1919 & Barbados & $A B C$ of sugarcane borer with hymenopteran parasitoids \\
\hline 1921 & Brazil & Import of a hymenopteran parasitoid for $\mathrm{CBC}$ of white peach scale \\
\hline 1927 & Dominican Republic & Finding of a fungal pathogen killing important weeds \\
\hline 1928 & Cuba & Import of coleopteran predator for CBC of cottony cushion scale \\
\hline 1930 & Haiti & Import of hymenopteran parasitoid for CBC of citrus blackfly \\
\hline 1931 & Panama & Import of hymenopteran parasitoid for $\mathrm{CBC}$ of citrus blackfly \\
\hline 1933 & Guyana & Import of tachinid parasitoid for $\mathrm{CBC}$ of sugarcane borer \\
\hline 1937 & Ecuador & Import of hymenopteran parasitoid for $\mathrm{CBC}$ of woolly apple aphid \\
\hline 1938 & French Guiana etc. & Import of tachinid parasitoid for $\mathrm{CBC}$ of sugarcane borer \\
\hline 1947 & Nicaragua & Documentation of hymenopteran parasitoids of fall armyworm \\
\hline 1950 & Bolivia & $\begin{array}{l}\text { Import of hymenopteran parasitoids and coleopteran predators for CBC } \\
\text { of cottony cushion scale, woolly apple aphid and olive scale }\end{array}$ \\
\hline 1950 & Dominica & Import of coleopteran predators for $\mathrm{CBC}$ of banana weevil \\
\hline 1967 & El Salvador & $\begin{array}{l}\text { Documentation of NC of saturniid butterflies on fruit trees by dipteran } \\
\text { and hymenopteran parasitoids }\end{array}$ \\
\hline 1969 & Belize & Import of hymenopteran parasitoids for $\mathrm{CBC}$ of fruit flies \\
\hline 1969 & Honduras & Import of hymenopteran parasitoids for $\mathrm{CBC}$ of fruit flies \\
\hline 1985 & Paraguay & $\begin{array}{l}\mathrm{ABC} \text { of soybean caterpillar with an entomopathogenic virus, and } \\
\text { sugarcane borer with hymenopteran parasitoids }\end{array}$ \\
\hline 1993 & Guatemala & $\begin{array}{l}\mathrm{ABC} \text { of diamondback moth in cruciferous crops with hymenopteran } \\
\text { parasitoid }\end{array}$ \\
\hline
\end{tabular}

agents has been published (van Lenteren $e t$ al., 2020) and an adapted version of these criteria is presented in Table 1.7. When searching for biocontrol agents, it is not unusual to find up to tens or even hundreds of species attacking a certain pest. This large number of potential candidate species stresses the need for evaluation criteria. The main aim of using these criteria is not to find the best natural enemy, but mostly to exclude unsuitable or problematic species quickly.
Most criteria concern biological characteristics of natural enemies (1-10), others relate to experience obtained in earlier biocontrol projects (11 and 13), economics of biocontrol (12 and 14), or to difficulties in importation and registration of exotic natural enemies (15). The relevance of these criteria is determined by the type of biocontrol programme one aims to develop. For example, in classical biocontrol, one will start with criterion 15 (how realistic it is to 
Table 1.7. Criteria for pre-introduction evaluation of biocontrol agents (adapted from van Lenteren et al., 2020).

\begin{tabular}{ll}
\hline No. & Criterion \\
\hline 1 & Seasonal synchronization with pest (mainly for classical biocontrol) \\
2 & Developmental synchronization with pest (mainly for classical biocontrol) \\
3 & Climatic adaptation to location where agent needs to be applied \\
4 & Capable of searching for pest on target crop and establishing a population \\
5 & No negative side effects \\
6 & Preference for pest species \\
7 & High pest-kill ability \\
8 & Good pest-finding capacity \\
9 & Responsiveness to changes in pest density \\
10 & Able to survive on alternative food in absence of pest (mainly for augmentative biocontrol) \\
11 & Same or similar species effective in same or similar crop and climate elsewhere \\
12 & Cost-effective mass production (mainly for augmentative biocontrol) \\
13 & Reliable performance \\
14 & Market potential (mainly for augmentative biocontrol) \\
15 & Potential for importation and/or registration of biocontrol agent \\
\hline
\end{tabular}

obtain a permit for importation and release of an exotic natural enemy), then criterion 11 (same or related species effective elsewhere), followed by collecting literature information about biological criteria $1-9$, while little attention is paid to issues 10 (ability to survive on alternative food), 12 (costs of mass rearing) and 14 (market potential). In the case of an augmentative biocontrol programme, evaluation starts with criteria 5 (not causing side effects), 12, 14 and 15 (costs of mass rearing, market potential, complexity of regulations).

Information obtained with computer searches and simple experiments related to criteria $1-6$ is often sufficient to reduce the number of potential candidates for biocontrol to fewer than ten species. After having excluded problematic species that may cause negative effects, or species that are clearly ineffective, research money can then be spent on the most promising candidates. Eventually, if testing under realistic production conditions reveals one or more effective biocontrol agents, these can be released in the case of classical biocontrol projects. However, if the agents will be used in augmentative biocontrol, it will be necessary to develop mass production, storage, shipment and release methods (van Lenteren and Tommasini, 2003). An important point for attention in mass production of biocontrol agents is quality control, and quality control protocols have been developed for a number of agents.
When a pest is of exotic origin, a foreign prospecting expedition may have to be organized. This was relatively easy in the past and many examples of using exotic natural enemies are presented in the country-specific chapters. However, for several decades many governments have demanded an environmental risk assessment before registering a new exotic biocontrol agent. More recently, since the adoption of the Nagoya protocol in 2014 (see below), very complicated and time-consuming procedures have to be followed before exotic species can be collected, imported and applied. As a result, prospecting for biocontrol agents now often starts with a search 'at home'.

The country-specific chapters in this book provide examples about prospecting for and evaluation of new biocontrol agents, as well as mass production and release methods.

\subsection{Regulations Concerning the Use of Biological Control Agents}

During the past 40 years a number of regulations have been developed that are related to import and release of biocontrol agents. Most countries, including those in the Latin American region, will have to comply with these regulations, in particular regulations developed and 
implemented by the Convention on Biological Diversity (SCBD, 2011). Many biocontrol researchers do not yet realize the serious impact of these regulations and so in this section we will discuss how new regulations delay or even seriously frustrate development and application of biocontrol.

Accidental introduction of exotic organisms has been occurring at an ever-growing rate during the past 150 years (Seebens et al., 2017) and increasing travel, trade and tourism will continue to result in the introduction of new pests. In contrast, deliberate introductions of many exotic biocontrol agents have caused remarkably few problems, while they have often resulted in permanent control of the unintentionally introduced pests (Cock et al., 2010). Many examples of this approach in biocontrol will be presented in this book, and especially during the period 1880-1970 many classical biocontrol projects were executed in Latin America and the Caribbean. Until a few years ago, prospecting for new, exotic biocontrol agents after unintended introductions of exotic pests was possible and usually occurred with the consent of the country where prospecting took place. However, due to recent developments concerning regulation and registration of biocontrol agents, and particularly as a result of the Nagoya protocol pertaining to exchange of biological resources, prospecting for biocontrol agents has practically come to a standstill (Cock et al., 2016).

During the first period of 'modern' biocontrol from 1880 to 1970 , hardly any regulations existed with regard to import and use of exotic agents, though many researchers were well aware of the risk of importing certain types of organisms, in particular generalist predators that might prey on non-target organisms. Two often cited and early problematic cases of biocontrol in the Latin American and Caribbean area - release of a mammal (mongoose) for control of rats and snakes and introduction of an amphibian (the giant toad) for control of insects were caused by amateurs, not by biocontrol experts. Most of the early introductions into the region concerned natural enemies that were earlier introduced for classical biocontrol in other countries, in particular the USA and countries of the former British Empire, and had not shown negative side effects. The Trinidad and
Tobago station of the predecessors of CABI played an important role in importing and releasing a number of exotic natural enemies in the Caribbean region and also organized many inter-island exchanges. All these releases, even if they consisted of somewhat polyphagous predators such as coccinellids, have apparently not led to negative effects, though it should be stressed that post-release environmental assessments have seldom been made. Still, we would classify them now as the hit-or-miss approach and we suppose that most countries would no longer allow such releases without environmental risk assessments.

Non-target effects of biocontrol agents were first considered in weed biocontrol, because of the risk that imported exotic herbivores might eat not only the weed, but also related plant species, including crops. It has since long been common practice to apply risk analyses in weed biocontrol and many countries demand such an analysis before a weed biocontrol agent can be imported and released (Wapshere, 1974; Sheppard et al., 2003). Risk analyses for candidate agents to control arthropod pests were developed much later and have only been applied since the 1980s. The reason is probably that very few problems had been reported about non-target effects caused by exotic invertebrates for arthropod biocontrol (Lynch et al., 2001). However, since the 1980s, when commercial augmentative biocontrol became popular and the number of exotic species applied in biocontrol strongly increased (see Fig. 2 in van Lenteren, 2012), many non-experts in the field of biocontrol started to release exotic agents. Thus, the need was felt for pre-release environmental risk assessments for new biocontrol agents to prevent non-target effects.

The first step towards risk assessments was the design a code of conduct for import and release of biocontrol agents by the Food and Agriculture Organization of the United Nations (FAO), together with CABI and IOBC (FAO, 1996). Since its development, the code of conduct has been used in CABI projects in the Caribbean and by a number of Latin American countries. Examples can be found in Kairo et al. (2003). Next, IOBC developed a set of standard methods to perform risk assessments, including practical guidance on how to measure and evaluate effects needed to draw conclusions 
about risks and benefits of biocontrol agents (Bigler et al., 2006). Environmental risk assessments are being demanded by a growing number of countries and are characterized by questions about: (i) the identity of the biocontrol agent; (ii) potential human health risks; (iii) potential environmental risks; and (iv) efficacy in controlling the pest (van Lenteren et al., 2006). Implementation of environmental risk assessment has resulted in a slowdown of newly marketed exotic biocontrol agents for augmentative biocontrol (see Figs 1 and 2 in van Lenteren, 2020) and introductions for classical biocontrol (see Fig. 1 in Cock et al., 2016). Preparation of extensive application dossiers also caused higher developmental costs, but did not bring prospecting for new non-native species to an end. This first phase of development of regulations was aimed at improving biocontrol, preventing potential negative effects and increasing confidence in biocontrol. Regulations for import and release, demands for environmental risk assessments and procedures for registration vary widely in Latin America and the Caribbean (see countryspecific chapters for details). Regional harmonization of these regulations might speed up registration and application of biocontrol agents. Still, harmonization is not expected to be an easy and quick process. Colmenarez et al. (Y.C. Colmenarez, Botucatu, Brazil, 2019, personal communication) propose the formation of a regional platform for harmonization of procedures related to biocontrol. In South America, the Plant Health Committee (Comité de Sanidad Vegetal (COSAVE)), a Regional Plant Protection Organization, might host such a platform.

A new and more recent phase of regulations was not developed to improve the science of biocontrol, but dealt with the question of who owns biocontrol agents. This question is related to one of the objectives of the Rio Convention on Biological Diversity (CBD, 1993): the fair and equitable sharing of the benefits arising from the utilization of genetic resources. Genetic resources are defined by CBD as genetic material, i.e. material containing functional units of heredity that is of actual or potential value, so this includes all biocontrol agents taken from one country (provider) to another (recipient) (Cock et al., 2010). As a result of this CBD objective, the Nagoya Protocol on Access and Benefit Sharing (ABS) was developed, which provides a framework for implementation of the fair and equitable sharing of benefits arising from the utilization of genetic resources (SCBD, 2011). The Nagoya Protocol came into force in October 2014 and is a potentially serious threat to the use of biocontrol, because there are no clear guidelines on how to develop agreements between the providing and recipient countries. The result is that prospecting for exotic natural enemies has currently been suspended due to lack of clear CBD and ABS procedures in many countries. The IOBC Global Commission on Access and Benefit Sharing (IOBC, 2019) made an appeal to develop ABS regulations that support the biocontrol sector by facilitating the exchange of biocontrol agents, including clear guidelines. These guidelines should also include fast-track procedures for finding and applying biocontrol agents in case of humanitarian or emergency situations, such as after unintentional export of an invasive pest to a new area. The IOBC also strongly recommended that biocontrol agents should be considered as a special case with respect to an ABS regime under the CBD (Cock et al., 2010). The IOBC recently prepared a best-practice guide for exchange of biocontrol genetic resources to assist the biocontrol community to demonstrate due diligence in complying with ABS requirements (Mason et al., 2018). This IOBC best-practice guide contains a section concerning gaining access to biocontrol agents and a draft ABS agreement for collection and study of biocontrol agents that can be used for scientific research and non-commercial release into nature by countries having signed the Nagoya Protocol (Mason et al., 2018). The draft agreement is designed to promote non-commercial activities, such as research in taxonomy, ecology and genetics, to foster biological conservation and the environmentally sound use of biocontrol agents. The objective is to provide a sound basis for cooperation, transparency, communication and trust between the parties and it will hopefully result in renewed prospecting for biocontrol agents to control invasive exotics. Similar to the issues of registration, risk assessment and regulations for import and release, the way in which the Latin American and Caribbean countries deal with the Nagoya protocol also shows great differences. 


\subsection{Structure of the Book}

After this introductory chapter, the history and current situation of biocontrol are presented for each Latin American or Caribbean country in the following 30 chapters. We introduce each country by mentioning the number of inhabitants and the major agricultural activities. This information often originated from three sources: (i) the IANAS 2017 Regional Report (IANAS, 2017), which contains a lot of information about the agricultural situation in the Americas; (ii) the website of the Central Intelligence Agency (CIA) of the USA (CIA, 2019), which has the most recent information about inhabitants and agricultural products for each country; and (iii) Wikipedia if data for inhabitants and agriculture could not be found in the first two sources.

Although the editors have tried to harmonize the structure of the chapters in which the countries present their history, current situation and future of biocontrol, different approaches can be observed. For example, authors of some countries discuss developments of biocontrol per crop (or group of crops), whereas other countries do this either per pest (or group of pests), or per type of biocontrol agent (e.g. predators, parasitoids, pathogens, microbial control agents and weed biocontrol agents). The editors asked the authors to estimate the area under biocontrol in their country and we have received estimates for many countries, but these were often said to be incomplete. For a few countries, data about areas under biocontrol could not be obtained. Thus, the figures mentioned in the country chapters, as well as in the summarizing chapter, will almost always be underestimates.

In the final chapter, we summarize achievements, discuss current factors stimulating and limiting the development of biocontrol and speculate about the future of biocontrol in Latin America and the Caribbean.

In order to help users of the book in finding projects related to certain species of biocontrol agents, pests and crops, there is a supplementary index that lists all scientific names of species with author names, order and family, as well as their common names and the countries in which the species were mentioned.

\section{References}

Aguilar, P. (1980) Apuntes sobre el control biológico y el control integrado de las plagas agrícolas en el Perú [Notes on biological control and integrated control of agricultural pests in Peru]. Revista Peruana de Entomología 23(1), 83-110.

Altieri, M.A. and Nichols, C.I. (1999) Classical biological control in Latin America. In: Bellows, T.S. and Fisher, T.W. (eds) Handbook of Biological Control. Academic Press, San Diego, California, pp. 975-991.

Altieri, M.A., Klein-Koch, C., Trujillo, J., Gold, C.S., Campos, L.S. and Quezada, J.R. (1989) El control biologico clasico en America Latina en su context historico [Classical biological control in Latin America in its historical context]. Manejo Integrado de Plagas, Costa Rica, No. 12, pp. 87-107.

Alves, S.B. and Lopes, R.B. (eds) (2008) Controle microbiano de pragas na América Latina [Microbial control of pests in Latin America]. Fapesp/Fealq, Piracicaba, SP, Brazil.

Arredondo-Bernal, H.C. and Rodríguez-del-Bosque, L.A. (eds.) (2008) Casos de Control Biológico en México [Cases of Biological Control in Mexico]. Ed. Mundi-Prensa México, Rio Pánuco, México DF.

Arredondo-Bernal, H.C. and Rodríguez-del-Bosque, L.A. (2015) Casos de Control Biológico en México [Cases of Biological Control in Mexico], Vol. 2. Biblioteca Básica de Agricultura, Colegio de Postgraduados, México DF.

Bale, J., van Lenteren, J.C. and Bigler, F. (2008) Biological control and sustainable food production. Philosophical Transactions of the Royal Society, Series B 363 (1492), 761-776. DOI: 10.1098/rstb.2007.2182

Barreto, R.W. (2008) Latin American weed biological control science at the crossroads In: Julien, M.H., Sforza, R., Bon, M.C., Evans, H.C., Hatcher, P.E., Hinz., H.L. and Rector, B.G. (eds) Proceedings of the XII International Symposium on Biological Control of Weeds. CAB International, Wallingford, UK, pp. 109-121.

Beingolea, O. (1990) Sinopsis sobre el control biológico de plagas insectiles en el Perú, 1909-1990 [Synopsis on the biological control of insect pests in Peru, 1909-1990]. Revista Peruana de Entomología 33, 105-112. 
Bennett, D. and Street, G. (1984) The Commonwealth Institute of Biological Control in integrated pest management programs in Latin America. In: Allen, G. and Rada, A. (ed.) Proceedings of the International Symposium: The role of biological control in pest management. IOBC/WPRS, Ottawa University Press, Ottawa, Canada, pp. 41-53.

Bentancourt, C.M. and Scatoni, I.B. (2001) Enemigos naturales: Manual ilustrado para la agricultura y la forestación [Biological control agents: Illustrated manual for agriculture and forestry]. Universidad de la República, Facultad de Agronomía, Montevideo, Uruguay.

Bettiol, W. and Morandi, M.A.B. (2009) Biocontrole de doenças de plantas: uso e perspectivas [Biological control of plant disease: use and perspectives]. Embrapa Meio Ambiente, Jaguariúna, São Paulo, Brazil.

Bettiol, W., Rivera, M.C., Mondino, P., Montealegre, J.R. and Colmenárez, Y.C. (2014) Control biológico de enfermedades de plantas en América Latina y el Caribe [Biological control of plant diseases in Latin America and the Caribbean]. Universidad de la Republica, Montevideo, Uruguay. Available at: http:// www.fagro.edu.uy/index.php/ documentos/category/46-libros-fagro.html (accessed 2 April 2019).

Bigler, F., Babendreier, D. and Kuhlmann, U. (2006) Environmental Impact of Invertebrates for Biological Control of Arthropods: Methods and Risk Assessment. CAB International, Wallingford, UK.

Bueno, V.H.P. (ed.) (2000) Controle Biológico de Pragas: Produção Massal e Controle de Qualidade [Biological pest control: mass production and quality control], 1st edn. Editora UFLA, Lavras, Brazil.

Bueno, V.H.P. (ed.) (2009) Controle Biológico de Pragas: Produção Massal e Controle de Qualidade [Biological pest control: mass production and quality control], 2nd edn. Editora UFLA, Lavras, Brazil.

CABI (2019a) CABI centres: Trinidad and Tobago. Available at: https://www.cabi.org/about-cabi/cabicentres/trinidad-and-tobago (accessed 7 July 2019).

CABI (2019b) CABI centres: Brazil. Available at: https://www.cabi.org/about-cabi/cabi-centres/brazil (accessed 7 July 2019).

Cabrera Walsh, G., Briano, J., Enrique de Briano, A. and Anderson, F.E. (2014) Malezas e invasoras de la Argentina (Invasive weeds in Argentina). In: Fernández, O.A., Leguizamón, E.S. and Acciaresi, H.A. (eds). Control Biológico de Malezas [Biological Control of Weeds]. Tomo I, Ecología y manejo. Editorial de la Universidad Nacional del Sur. Ediciones. Bahía Blanca, Argentina, pp. 801-821.

CARDI (2019) Welcome to CARDI. Available at: http://www.cardi.org/ (accessed 7 July 2019).

Carreño, A.M. (2001) Fundamentos de control biológico de plagas plagas [Fundamentals of biological pest contro/]. Universidad Nacional de Colombia sede Medellín, Colombia.

CBD (Convention on Biological Diversity) (1993) Convention on Biological Diversity (with annexes). Concluded at Rio de Janeiro on 5 June 1992. United Nations - Treaty Series 1760(30619), pp. 142-382.

CIA (2019) The World Factbook. Available at: https://www.cia.gov/library/publications/the-world-factbook (accessed 7 July 2019).

Cock, M.J.W. (ed) (1985) A review of biological control of pests in the Commonwealth Caribbean and Bermuda up to 1982. Technical Communication No. 9, Commonwealth Institute of Biological Control. Commonwealth Agricultural Bureaux, Farnham Royal, UK.

Cock, M.J.W., van Lenteren, J.C., Brodeur, J., Barratt, B.I.P., Bigler, F., Bolckmans, K., Consoli, F.L., Haas, F., Mason, P.G. and Parra, J.R.P. (2010) Do new access and benefit sharing procedures under the convention on biological diversity threaten the future of biological control? BioControl 55, 199-218.

Cock, M.J.W., Murphy, S.T., Kairo, M.T.K., Thompson, E., Murphy, R.J. and Francis, A.W. (2016) Trends in the classical biological control of insect pests by insects: an update of the BIOCAT database. BioControl 61, 349-363. DOI: 10.1007/s10526-016-9726-3.

Cotes, A.M. (ed.) (2018) Control biológico, de fitopatógenos, insectos y ácaros [Biological control of phytopathogens, insects and mites]. Vol 1. Applicaciones y perspectivas [Applications and perspectives]. Vol 2. Agentes de control biológico [Biological control agents]. AgroSavia Editores, Mosquera, Colombia, 566. Available at: http://hdl.handle.net/20.500.12324/33829 and http://hdl.handle.net/20.500.12324/ 33519 (accessed 2 April 2019)

DeBach, P. (1964) Biological Control of Insect Pests and Weeds. Chapman and Hall, London, UK.

DeBach, P. (1974) Biological Control by Natural Enemies. Cambridge University Press, Cambridge, UK.

DeLoach, C., Cordo, H.A. and Crouzel, I.S. (1989) Control biológico de malezas [Biological control of weeds]. Editorial El Ateneo, Buenos Aires, Argentina.

FAO (1996) Code of conduct on the import and release of biological control agents. FAO, Rome. Available at: www.fao.org (accessed 2 April 2019).

FAO (2019) Priorities. Available at: http://www.fao.org/americas/en/ (accessed 2 April 2019).

FAO/IPPC (1997) International Plant Protection Convention. FAO, Rome. Available at: www.fao.org (accessed 2 April 2019). 
Ferrer, F. (2001) Biological control of agricultural insect pests in Venezuela: advances, achievements, and future perspectives. Biocontrol News and Information 22(3), 67-74.

Fuentes, F., Ferrer, F.R. and Salas, J.L. (2012) Reseña Histórica del Control Biológico en Centroamérica y el Caribe [History of biological control in Central America and the Caribbean]. Ed. Académica Española, LAP LAMBERT Academic Publishing GmbH \& Co., Saarbrucken, Germany.

Gallardo-Covas, F. (2017) Biological control of insect pests in Puerto Rico. Journal of Agriculture of the University of P.R. 101, 153-163.

Greathead, D.J. (1994) History of biological control. Antenna 18, 187-199.

Hagen, K.S. and Franz, J.M. (1973) A history of biological control. In: Smith, R.F., Mittler, T.E. and Smith, C.N. (eds) History of Entomology. Annual Reviews Inc., Palo Alto, California, pp. 433-476.

Heimpel, G.E. and Mills, N.J. (2017) Biological Control: Ecology and Applications. Cambridge University Press, Cambridge, UK.

Hilje, L. and Saunders, J.I. (2008) Manejo integrado de plagas en Mesoamérica: aportes conceptuales [Integrated pest management in Mesoamerica: conceptual contributions]. Editorial Tecnológica de Costa Rica, Cartago, Costa Rica.

Hokkanen, M.T. and Pimentel, D. (1989) New associations in biological control: theory and practice. Canadian Entomologist 121, 829-840.

IANAS Regional Report (2017) Challenges and Opportunities for Food and Nutrition Security in the Americas. The View of the Academies of Sciences. The Inter-American Network of Academies of Sciences (IANAS-IAP), Ciudad de México, Mexico. Available in English and Spanish at: www.ianas.org (accessed 2 April 2019).

IOBC (2019) IOBC Global Commission on Biological Control and Access and Benefit Sharing. Available at: http://www.iobc-global.org/global_comm_bc_access_benefit_sharing.html (accessed 7 July 2019).

Kairo, M.T.K., Cock, M.J.W. and Quinlan, M.M. (2003) An assessment of the use of the Code of Conduct for the Import and Release of Exotic Biological Control Agents (ISPM No. 3) since its endorsement as an international standard. Biocontrol News and Information $200324(1), 15 \mathrm{~N}-27 \mathrm{~N}$.

Klein-Koch, C. (1989) El control biológico de plagas en Ecuador [Biological control of pests in Ecuador]. Ministerio de Agricultura y GTZ, Quito, Ecuador. Sanidad Vegetal 4(4), 5-20.

Lockwood, J.A. (1993) Environmental issues involved in biological control of rangeland grasshoppers (Orthoptera: Acrididae) with exotic agents. Environmental Entomology 22, 503-518.

Lynch, L.D., Hokkanen, H.M.T., Babendreier, D., Bigler, F., Burgio, G., Gao, Z.H., Kuske, S., Loomans, A.J.H.M., Menzler-Hokkanen, I., Thomas, M.B., Tommasini, M.G., Waage, J., van Lenteren, J.C. and Zeng, Q.Q. (2001) Indirect effects in the biological control of arthropods with arthropods. In: Wajnberg, E., Scott, J.C. and Quimby, P.C. (eds.) Evaluating Indirect Ecological Effects of Biological Control. CAB International, Wallingford, UK, pp. 99-125.

Mason, P.G., Cock, M.J.W., Barratt, B.I.P, Klapwijk, J., van Lenteren, J.C., Brodeur, J., Hoelmer, K.A. and Heimpel, G.E. (2018) Best practices for the use and exchange of invertebrate biological control genetic resources relevant for food and agriculture. BioControl 63, 149-154. DOI: 10.1007/s10526-017-9810-3

McEvoy, P.B. (2018) Theoretical contributions to biological control success. BioControl 63, 87-103. DOI: 10.1007/s10526-017-9852-6

Millennium Ecosystem Assessment (2005) Ecosystems and Human Well-being: Synthesis. Island Press, Washington, DC.

Nordlund, D.A. (1996) Biological control, integrated pest management and conceptual models. Biocontrol News and Information 17, 35N-44N.

Palacios, F. (ed.) (1993) Control biológico en Colombia: historia, avances y proyecciones [Biological control in Colombia: history, progress and projections]. Universidad Nacional de Colombia, Palmira, Colombia.

Parra, J.R.P., Botelho, P.S.M., Corrêa-Ferreira, B.S. and Bento, J.M.S. (2002) Controle Biológico no Brasil. Parasitóides e Predadores [Biological Control in Brazil. Parasitoids and Predators]. Ed.Manole, São Paulo, Brazil.

Pérez-Gelabert, D. (2008) Arthropods of Hispaniola (Dominican Republic and Haiti): A checklist and bibliography. Zootaxa 1831, 1-530.

Ravensberg, W.J. (2011) A Roadmap to the Successful Development and Commercialization of Microbial Pest Control Products for Control of Arthropods. Springer, Dordrecht, Netherlands.

Rogg, H.W. (2000a) Manual de Entomología Agrícola de Bolivia [Handbook of Agricultural Entomology of Bolivia]. Abya-Yala, Quito, Ecuador.

Rogg, H.W. (2000b) Manual Manejo Integrado de Plagas en Cultivos Tropicales [Handbook of Integrated Pest Management in Tropical Crops]. Abya-Yala, Quito, Ecuador. 
Rojas, S. (2005) Control biológico de plagas en Chile. Historia y avances [Biological control of pests in Chile. History and advances]. Instituto de Investigaciones Agropecuarias. Centro Regional de Investigación La Platina. Edit. Ograma, La Cruz, Chile.

Ryckewaert, P. and Rhino, B. (2017) Insectes et acariens des cultures maraîchères en milieu tropical humide: reconnaissance, bio-écologie et gestion agro-écologique [Insects and mites of vegetable crops in humid tropical environment: recognition, bio-ecology and agro-ecological management]. Ed. Quae,Versailles, France.

SCBD (Secretariat of the Convention on Biological Diversity) (2011) Nagoya protocol on access to genetic resources and the fair and equitable sharing of benefits arising from their utilization to the Convention on Biological Diversity: text and annex. Convention on Biological Diversity, United Nations, Montreal, Canada.

Seebens, H., Blackburn, T.M., Dyer, E.E., Genovesi, P., Hulme, P.E. et al. (2017) No saturation in the accumulation of alien species worldwide. Nature Communications 8, 14435.

Sheppard, A.W., Hill, R.L., DeClerck-Floate, R.A., McClay, A., Olckers, T., Quimby, P.C. and Zimmermann, H.G. (2003) A global review of risk-benefit-cost analysis for the introduction of classical weed biological control agents against weeds: a crisis in the making? Biocontrol News and Information 24(4), 91N-108N.

Stiling, P. and Cornelissen, T. (2005) What makes a successful biocontrol agent? A meta-analysis of biological control agent performance. Biological Control 34, 236-246. DOI: 10.1016/j.biocontrol.2005.02.017.

van Dinther, J.B.M. (1960) Insect pests of cultivated plants in Surinam. Bulletin Agricultural Experiment Station Suriname 76, 1-159.

van Driesche, R.D. and Bellows, T.S. (1996) Biological Control. Chapman \& Hall, New York.

van Lenteren, J.C. (1980) Evaluation of control capabilities of natural enemies: does art have to become science? Netherlands Journal of Zoology 30, 369-381.

van Lenteren, J.C. (1986) Parasitoids in the greenhouse: successes with seasonal inoculative release systems. In: Waage, J.K. and Greathead, D.J. (eds) Insect Parasitoids. Academic Press, London, pp. 341-374.

van Lenteren, J.C. (2012) The state of commercial augmentative biological control: plenty of natural enemies, but a frustrating lack of uptake. BioControl 57, 71-84 + supplemental material. DOI: 10.1007/ s10526-011-9395-1

van Lenteren, J.C. (2020) Will the 'Nagoya Protocol on Access and Benefit Sharing' put an end to biological control? In: Hendrichs, J., Pereira, R. and Vreysen, M.J.B. (eds) Area-wide Integrated Pest Management: Development and Field Application. FAO/IAEA, Vienna, Austria.

van Lenteren, J.C. and Bueno, V.H.P. (2003) Augmentative biological control of arthropods in Latin America. BioControl 48, 123-139.

van Lenteren, J.C. and Tommasini, M.G. (2003) Mass production, storage, shipment and release of natural enemies. In: van Lenteren, J.C. (ed.) Quality Control and Production of Biological Control Agents: Theory and Testing Procedures. CAB International, Wallingford, UK, pp. 181-189.

van Lenteren, J.C., Bale, J., Bigler, F., Hokkanen, H.M.T. and Loomans, A.J.M.(2006) Assessing risks of releasing exotic biological control agents of arthropod pests. Annual Review of Entomology 51, 609-634 + supplemental material. DOI: 10.1146/annurev.ento.51.110104.151129

van Lenteren, J.C., Bueno, V.H.P., Burgio, G., Lanzoni, A., Montes, F.C., Silva, D.B., de Jong, P.W. and Hemerik, L. (2019) Pest kill rate as aggregate evaluation criterion to rank biological control agents: a case study with Neotropical predators of Tuta absoluta on tomato. Bulletin of Entomological Research 109. DOI: $10.1017 /$ S0007485319000130

Vázquez, L.L. and Pérez, N. (2016) Control biológico [Biological control]. In: Funes, F. and Vázquez, L.L. (eds) Avances de la agroecología en Cuba. Estación experimental de Pastos y Forrajes Indio Hatuey, Matanzas, pp. 169-182.

Waage, J.K. and Greathead, D.J. (1988) Biological control: challenges and opportunities. Philosophical Transactions of the Royal Society, London, Series B 318, 111-128.

Wapshere, A.J. (1974) A strategy for evaluating the safety of organisms for biological weed control. Annals of Applied Biology 77, 201-211.

Wyckhuys, K.A., Lu, Y., Morales, H., Vazquez, L.L., Legaspi, J.C., Eliopoulos, P.A. and Hernandez, L.M. (2013) Current status and potential of conservation biological control for agriculture in the developing world. Biological Control, 65, 152-167.

Zapater, M.C. (ed.) (1996) El Control Biológico en América Latina [Biological Control in Latin America]. IOBC/NTRS, Buenos Aires, Argentina. 